J. Akademika Kim. 6(2): 113-118, May 2017

ISSN 2302-6030 (p), 2477-5185 (e)

\title{
PENGARUH MODEL PEMBELAJARAN GUIDED INQUIRY DENGAN MIND MAPTERHADAP HASIL BELAJAR DAN MOTIVASI SISWA PADA MATERI REDOKS DI KELAS X SMA NEGERI 5 PALU
}

\author{
Effect of Guided Inquiry Learning Model with Mind Map Toward Learning \\ Achievement and Motivation of Students on Reduction-Oxidation in the Class X \\ at SMA 5 Palu
}

\author{
*Regina S. Lumentut, Irwan Said, dan Kasmudin Mustapa \\ Pendidikan Kimia/FKIP - Universitas Tadulako, Palu - Indonesia 94118 \\ Recieved 10 March 2017, Revised 12 April 2017, Accepted 11 May 2017
}

\begin{abstract}
This study aimed to investigate the effect of guided inquiry learning model with mind map toward learning achievement and motivation of students on Reduction-Oxidation in the Class X at SMA 5 Palu. This study was a quasi-experimental design with a non-randomized pretest-posttest control group design. This study was carried out by holding two groups of Class $X$ Sciences 1 as the experimental group $(n=31)$ and Class $X$ Sciences 2 as the control group $(n=32)$. Testing of learning achievement data of students used t-test statistical analysis of two parties with the prerequisite tests: normality and homogeneity tests of written test given after learning (posttest). Results of the data analysis showed the average value of the experimental class was 56.48 with a standard deviation of 11.07, and () of the control class was 46.25 with a standard deviation of 11.98. Based on the hypothesis test results with $t$-test statistical of two parties obtained $-t_{\text {table }} \leq t_{\text {count }} \geq+t_{\text {table }}\left(t_{\text {count }}=2.43\right.$ and $\left.t_{\text {table }}=1.67\right)$ with a significance level of $\alpha=0.05$ and degrees of freedom of 61 , then $\mathrm{HO}$ is rejected and $\mathrm{Ha}$ is accepted. Results of the data analysis of students motivation by using descriptive statistical analysis from the questionnaire of students motivation showed that the experimental class was currently on attitudes agree with the positive category of $82.58 \%$, and the control class was on attitudes agree with the positive category of $83.78 \%$. It can be concluded that there was an effect of guided inquiry learning model with mind map toward learning achievement of students, but it had no effect on the motivation of students in the Class $X$ at SMA 5 Palu on Reduction-Oxidation
\end{abstract}

Keywords: Guided Inquiry, Mind Map, Learning Achievement, Motivation, Reduction-Oxidation

\section{Pendahuluan}

Pendidikan berperan penting dalam kehidupan manusia, seiring berkembangnya teknologi dan zaman, pendidikan pun mengalami perkembangan (Wulandari, dkk., 2013). Perkembangan zaman yang semakin modern terutama pada era globalisasi seperti saat ini menuntut berbagai perubahan yang mendasar dalam berbagai bidang termasuk bidang pendidikan. Pelaksanaan perubahan pendidikan tersebut, sejak tahun 1998 UNESCO mengemukakan empat pilar belajar yaitu belajar mengetahui (learning to know),

*Correspondence:

Regina S. Lumentut

Program Studi Pendidikan Kimia, Fakultas Keguruan dan

Ilmu Pendidikan, Universitas Tadulako

email: reginalumentut03@gmail.com

Published by Universitas Tadulako 2017

belajar melakukan (learning to do), belajar hidup dalam kebersamaan (learning to live together), dan belajar menjadi diri sendiri (learning to be) (Mulyasa, 2014).

Diterapkannya kurikulum 2013 bertujuan untuk menghasilkan insan Indonesia yang produktif, kreatif, inovatif, dan afektif melalui penguatan sikap, pengetahuan, dan keterampilan. Desain pembelajaran dari penerapan kurikulum 2013 harus menciptakan pola pembelajaran yang interaktif dan mengubah sistem pembelajaran yang terisolasi menjadi pembelajaran secara jejaring. Pendekatan pembelajaran yang disarankan dan menjadi karakter dari kurikulum 2013 yaitu pendekatan ilmiah (scientific approach) yang prosedur penerapannya memiliki tahapan yaitu menanya, mencoba, mengasosiasi, kemudian 
mengomunikasikan yang diharapkan dapat menghasilkan peserta didik yang mumpuni baik di bidang sikap, pengetahuan, dan keterampilan (Putri, dkk., 2014).

Kimia pada hakekatnya merupakan cara mencari tahu dan memahami tentang alam secara sistematis, sehingga kimia tidak diajarkan hanya dengan sekedar memberikan pemahaman tentang pengertian-pengertian, fakta-fakta, konsep-konsep, prinsip-prinsip, tetapi juga merupakan penemuan melalui proses pencarian dengan tindakan nyata (inkuiri) (Maliha, 2011).

Konsep dalam ilmu kimia bersifat abstrak dan saling berkaitan, termasuk pada materi redoks. Mempelajari konsep redoks diperlukan pemahaman konseptual dan algoritmik (Aini, 2011). Materi reaksi redoks yang bersifat abstrak cocok bila dibelajarkan kepada siswa dengan model pembelajaran yang melibatkan siswa secara aktif dalam menemukan konsepkonsep dalam materi reaksi oksidasi reduksi. Model pembelajaran yang sesuai antara lain adalah model pembelajaran inkuiri terbimbing (Wiyatsih, 2011).

Model pembelajaran guided inquiry (inkuiri terbimbing) merupakan model pembelajaran yang mempunyai langkahlangkah untuk memecahkan masalah, merencanakan eksperimen, melakukan eksperimen, mengumpulkan dan menganalisis data, dan menarik kesimpulan (Wahyudin, dkk., 2010). Proses inkuiri, siswa terlibat secara mental maupun fisik untuk memecahkan permasalahan yang diberikan guru. Siswa akan terbiasa bersikap seperti ilmuwan, yaitu teliti, objektif, kreatif, dan menghormati pendapat orang lain (Dewi, 2012).

Karakteristik inkuiri terbimbing (guided inquiry), yaitusiswabelajaraktifdan terefleksikan pada pengalaman, belajar berdasarkan pada apa yang mereka tahu, mengembangkan rangkaian berpikir dalam proses pembelajaran melalui bimbingan, perkembangan siswa terjadi secara bertahap, mempunyai cara yang berbeda dalam pembelajaran, dan belajar melalui interaksi sosial dengan orang lain (Kuhlthau, 2010). Proses inquiry terdiri dari mengidentifikasi dan menyelesaikan kontradiksi, menggeneralisasi, menyimpulkan, dan memecahkan masalah (Zawadzki, 2010).

Mind map (peta pikiran) merupakan teknik meringkas bahan yang akan dipelajari dan memproyeksikan masalah yang dihadapi ke dalam bentuk peta atau teknik grafik sehingga lebih mudah memahaminya (Lukman, dkk., 2015). Pembelajaran dengan metode mind mapping didalamnya siswa dikuatkan pada cara menghadapi persoalan dengan langkah penyelesaian yang sistematis yaitu memahami masalah, menyusun rencana, melaksanakan rencana, dan memeriksa kembali sehingga persoalan yang dihadapi akan dapat diatasi (Wigiani, dkk., 2012). Hal tersebut dapat sejalan dengan langkah-langkah dalam model pembelajaran guided inquiry, sehingga peneliti bermaksud memadukan model pembelajaran guided inquiry dengan mind map. Pembelajaran dengan menggunakan mind map akan meningkatkan daya hafal dan motivasi belajar siswa yang kuat, serta siswa menjadi lebih kreatif (Buzan, 2007).

Hasil belajar merupakan perubahan perilaku siswa akibat belajar. Perubahan itu diupayakan dalam proses belajar mengajar untuk mencapai tujuan pendidikan. Perubahan perilaku disebabkan karena siswa mencapai penguasaan atas sejumlah bahan yang diberikan dalam proses belajar mengajar (Purwanto, 2013). Hasil belajar adalah kemampuan yang dimiliki baik bersifat pengetahuan (kognitif), sikap (afektif), maupun keterampilan (psikomotorik) yang semuanya ini diperoleh melalui proses belajar mengajar (Mappeasse, 2009). Faktorfaktor yang mempengaruhi hasil belajar siswa dari dalam adalah minat dan motivasi belajar siswa (Aritonang, 2008).

Motivasi menjelaskan mengapa ada orang berperilaku tertentu untuk mencapai serangkaian tujua, dengan adanya motivasi, siswa akan belajar lebih keras, ulet, tekun dan memiliki konsentrasi penuh dalam proses belajar pembelajaran. Dorongan motivasi dalam belajar merupakan salah satu hal yang perlu dibangkitkan dalam upaya pembelajaran di sekolah (Hamdu \& Agustina, 2011).

Tulisan ini dimaksudkan untuk menganalisis ada tidaknya pengaruh model pembelajaran guided inquiry dengan mind map terhadap hasil belajar dan motivasi siswa pada materi redoks di kelas X SMA Negeri 5 Palu.

\section{Metode}

Penelitian ini dilaksanakan di SMA Negeri 5 Palu. Populasi dari penelitian ini adalah seluruh siswa kelas X SMA Negeri 5 Palu yang terdaftar pada tahun ajaran 2015/2016 sebanyak 5 kelas. Sampel dalam penelitian ini terdiri dari 2 kelas yaitu kelas X MIPA 1 sebagai kelas eksperimen dan kelas X MIPA 2 sebagai kelas kontrol. Teknik pengambilan sampel dengan cara purposive sampling (sampling pertimbangan) dengan melihat jumlah siswa yang hampir sama, yaitu 31 siswa untuk kelas eksperimen 
dan 32 untuk kelas kontrol dan berdasarkan nilai rata-rata hasil belajar siswa di semester sebelumnya yang juga hampir sama

\section{Instrumen Penelitian}

Instrumen yang digunakan pada penelitian ini adalah tes hasil belajar bentuk pilihan ganda sebanyak 40 soal dengan 20 pilihan tervalidasi yang disusun untuk mengetahui ada tidaknya pengaruh model pembelajaran guided inquiry dengan mind map terhadap hasil belajar siswa. Selain itu, digunakan instrumen berupa angket motivasi sebanyak 25 item yang disusun dengan maksud untuk memperoleh data motivasi belajar siswa setelah proses belajar-mengajar, sehingga di ketahui ada tidaknya pengaruh model pembelajaran guided inquiry dengan mind map terhadap motivasi belajar siswa.

\section{Teknik Pengumpulan Data \\ Tahap Persiapan}

Langkah-langkah yang dilakukan pada tahap ini, yaitu observasi lokasi penelitian, menentukan populasi dan sampel penelitian, menyusun instrumen tes, merancang skenario pembelajaran berupa rencana pelaksanaan pembelajaran (RPP) berdasarkan kurikulum 2013 yang akan digunakan dalam penelitian dengan alokasi waktu $6 \times 45$ menit.

\section{Tahap Pelaksanaan}

Langkah-langkah yang dilakukan pada tahap ini, yaitu pemberian tes awal sebelum melakukan perlakuan atau proses belajar (pretest), pemberian perlakuan (penyajian materi), kelas eksperimen diberikan perlakuan dengan menerapkan model pembelajaran guided inquiry dengan mind map dan kelas kontrol menerapkan metode diskusi kelompok, dan selanjutnya pemberian tes evaluasi dan angket motivasi pada kelas eksperimen dan kelas kontrol untuk memperoleh data hasil belajar dan motivasi siswa (Postest).

\section{Tahap Akhir}

Kegiatan yang dilakukan pada tahap ini adalah pengumpulan, pengolahan dan analisis data serta pelaporan hasil penelitian.

\section{Hasil dan Pembahasan}

Hasil Belajar Siswa

Berdasarkan penelitian yang
akukan, didapatkan data hasil belajar siswa kelas eksperimen maupun kelas kontrol, terdapat pada tabel 1:

Data hasil belajar kemudian dianalisis menggunakan analisis statistik deskriptif dan
Tabel 1. Perbandingan Hasil Belajar Siswa Kelas Eksperimen dan Kontrol

\begin{tabular}{ccc}
\hline \multirow{2}{*}{ Uraian } & \multicolumn{2}{c}{ Tes Akhir (Postest) } \\
\cline { 2 - 3 } & Kelas eksperimen & Kelas kontrol \\
\hline Sampel & 31 & 32 \\
Nilai terendah & 40 & 25 \\
Nilai tertinggi & 85 & 80 \\
Skor rata-rata & 56,48 & 46,25 \\
Standar deviasi & 11,07 & 11,98 \\
\hline
\end{tabular}

analisis statistik inferensial (Sugiyono, 2010). Analisis statistik deskriptif yang digunakan, yaitu uji $\mathrm{N}$-gain untuk menentukan hubungan nilai pretest dan postest kelas eksperimen dan kelas kontrol atau melihat peningkatan hasil belajar siswa berdasarkan data pretest dan postest (Wulandari, dkk., 2013). Pengujian N-gain yang diperoleh adalah sebagai berikut:

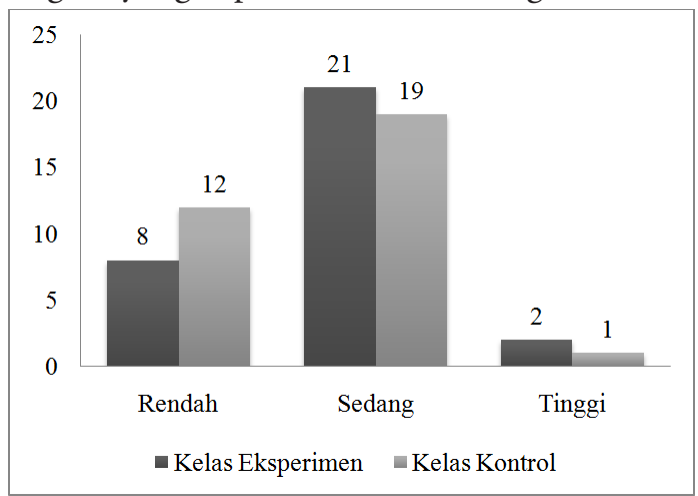

Gambar 1. Grafik Pengujian N-Gain Siswa Di Kelas Eksperimen Dan Kelas Kontrol

Berdasarkan grafik di atas, terdapat peningkatan hasil belajar kelas eksperimen dan kelas kontrol, dimana hasil belajar kelas eksperimen lebih tinggi dari kelas kontrol. Sedangkan untuk analisis statistik inferensial dengan menggunakan uji-t dua pihak yang diperoleh dari harga $t_{(0.95)}$ dengan $\mathrm{dk}=61$ dari daftar distribusi siswa adalah 1,67, kriteria pengujian adalah jika $\left.-\mathrm{t}_{\text {tabel }}\right\urcorner \leq \mathrm{t}_{\text {hitung }} \leq+\mathrm{t}_{\text {tabel }}(1-$ $\alpha),(\mathrm{n} 1+\mathrm{n} 2-2)$ terima H0 dan Ha ditolak. Berdasarkan hasil diperoleh $-1,67 \leq 2,43 \geq$ $+1,67$ jelas berada pada daerah penolakan $\mathrm{H} 0$ sehingga $\mathrm{H} 0$ ditolak dan $\mathrm{Ha}$ diterima, maka dapat disimpulkan bahwa ada pengaruh model pembelajaran guided inquiry dengan mind map terhadap hasil belajar siswa kelas X SMA Negeri 5 Palu pada materi redoks. Penelitian ini menggunakan taraf kepercayaan 0,05 karena diharapkan dalam pengambilan kesimpulan, kesalahan yang terjadi hanya 5\% dan 95\%-nya benar. Data yang diperoleh dengan pengujian hipotesis terlebih dahulu dilakukan beberapa pengujian prasyarat, 
yaitu uji normalitas dan homogenitasnya.

Tabel 2. Hasil uji statistik terhadap hasil belajar siswa

\begin{tabular}{|c|c|c|c|c|c|c|c|c|}
\hline \multirow[b]{2}{*}{ Kelas } & \multirow[b]{2}{*}{$N$} & \multicolumn{3}{|c|}{ Uji Normalitas } & \multicolumn{3}{|c|}{ Uji Homogenitas } & \multirow[b]{2}{*}{ Uji t } \\
\hline & & $\chi^{2}$ hit & $\chi_{\text {tab }}^{2}$ & $\begin{array}{c}\text { Kesim- } \\
\text { pulan }\end{array}$ & $F_{\text {hit }}$ & $F_{\text {tab }}$ & $\begin{array}{c}\text { Kesim- } \\
\text { pulan }\end{array}$ & \\
\hline \multirow[t]{2}{*}{ Eksperimen } & 31 & 6,89 & 7,81 & Terdistri- & & & & $t_{\text {hit }}=1,67$ \\
\hline & & & & busi & 1,08 & 2,38 & Homogen & $\mathrm{t}_{\mathrm{tab}}=2,43$ \\
\hline Kontrol & 32 & 4,19 & 5,99 & normal & & & & $\alpha=0,05$ \\
\hline
\end{tabular}

Berdasarkan data yang diperoleh baik pada uji statistik deskrptif maupun statistik inferensial model pembelajaran guided inquiry dengan mind map memiliki pengaruh dengan hasil yang lebih tinggi terhadap hasil belajar siswa sebagai akibat dari kelebihan-kelebihan yang menjadi ciri khas dari model pembelajaran guided inquiry, yaitu dapat membentuk dan mengembangkan "Self Concept" pada siswa, sehingga siswa dapat mengerti tentang konsep dasar dan ide-ide yang lebih baik (Roestiyah, 2008) dan kelebihan dari mind map, yaitu memduahkan siswa untuk mudah mengingat fakta, angka, dan rumus dengan mudah dan cepat. Hal tersebut sesuai dengan penelitian (Mutrovina \& Syarief, 2015) yang menunjukkan bahwa hasil belajar siswa dengan penerapan model pembelajaran inkuiri terbimbing pada materi reaksi reduksi dan oksidasi sangat baik (nilai rata-rata siswa sebesar 3,28 dan ketuntasan klasik hasil belajar siswa sebesar 94,1\%).

\section{Motivasi Siswa}

Berdasarkan penelitian yang dilakukan, didapatkan data motivasi belajar siswa kelas eksperimen maupun kelas kontrol, sebagai berikut:

Tabel 3. Perbandingan Motivasi Belajar Siswa Kelas Eksperimen dan Kontrol

\begin{tabular}{ccc}
\hline Uraian & Kelas Eksperimen & Kelas Kontrol \\
\hline Jumlah Siswa & 31 & 32 \\
Skor Minimal & 90 & 77 \\
Skor Maksimal & 125 & 125 \\
\% Rata-Rata & 82,58 & 83,78 \\
Sikap & Setuju & Setuju \\
Kategori & Positif & Positif \\
\hline
\end{tabular}

Data di atas menunjukkan bahwa penerapan model pembelajaran guided inquiry dengan mind map tidak berpengaruh terhadap motivasi belajar siswa, karena kelas yang diterapkan model pembelajaran guided inquiry dengan mind map maupun diskusi kelompok samasama berada pada sikap setuju dan kategori positif. Angket motivasi yang digunakan pada penelitian ini terdiri dari lima indikator motivasi yang dijabarkan dalam setiap pernyataan angket dengan nilai rata-rata persentasenya untuk kelas eksperimen dan kelas kontrol.

Tabel 4. Data Hasil Motivasi Belajar Siswa Kelas Eksperimen

\begin{tabular}{|c|c|c|c|c|c|c|c|c|}
\hline No & Indikator & $\begin{array}{c}\text { Jumlah } \\
\text { no.soal }\end{array}$ & $\begin{array}{l}\text { Skor } \\
\text { maks }\end{array}$ & $\begin{array}{l}\text { Skor } \\
\text { total }\end{array}$ & $\begin{array}{l}\text { Rata- } \\
\text { rata }\end{array}$ & $\%$ & Sikap & Kategori \\
\hline 1 & Perhatian & $1,2,3,4,5$ & 775 & 639 & 4,12 & 82,45 & Setuju & Positif \\
\hline 2 & Ketertarikan & $6,7,8,9,10$ & 775 & 646 & 4,17 & 83,35 & Setuju & Positif \\
\hline 3 & Keaktifan & $11,12,13,14,15$ & 775 & 629 & 4,06 & 81,16 & Setuju & Positif \\
\hline 4 & Kepuasan & $16,17,18,19,20$ & 775 & 631 & 4,07 & 81,42 & Setuju & Positif \\
\hline 5 & Keyakinan & $21,22,23,24,25$ & 775 & 655 & 4,23 & 84,52 & $\begin{array}{l}\text { Sangat } \\
\text { setuju }\end{array}$ & Positif \\
\hline
\end{tabular}

Tabel 5. Data Hasil Motivasi Belajar Siswa Kelas Kontrol

\begin{tabular}{|c|c|c|c|c|c|c|c|c|}
\hline No & Indikator & $\begin{array}{l}\text { Jumlah } \\
\text { no.soal }\end{array}$ & $\begin{array}{l}\text { Skor } \\
\text { maks }\end{array}$ & $\begin{array}{l}\text { Skor } \\
\text { total }\end{array}$ & $\begin{array}{l}\text { Rata- } \\
\text { rata }\end{array}$ & $\%$ & Sikap & Kategori \\
\hline 1 & Perhatian & $1,2,3,4,5$ & 800 & 667 & 4,17 & 83,38 & Setuju & Positif \\
\hline 2 & Ketertarikan & $6,7,8,9,10$ & 800 & 662 & 4,14 & 82,75 & Setuju & Positif \\
\hline 3 & Keaktifan & $11,12,13,14,15$ & 800 & 673 & 4,21 & 84,13 & Setuju & Positif \\
\hline 4 & Kepuasan & $16,17,18,19,20$ & 800 & 679 & 4,24 & 84,88 & $\begin{array}{c}\text { Sangat } \\
\text { setuju }\end{array}$ & Positif \\
\hline 5 & Keyakinan & $21,22,23,24,25$ & 800 & 670 & 4,19 & 83,75 & Setuju & Positif \\
\hline \multicolumn{3}{|c|}{ Jumlah dan Rata-rata } & 4000 & 3351 & 4,19 & 83,78 & Setuju & Positif \\
\hline
\end{tabular}

Tingkat ketertarikan dan keyakinan siswa kelas eksperimen yang menunjukkan persentase lebih tinggi dari pada kelas kontrol, dapat menjelaskan hubungan antara hasil belajar dan motivasi siswa, di mana hasil belajar siswa kelas eksperimen lebih tinggi dari pada kelas eksperimen, hal tersebut dapat dipengaruhi oleh banyak hal, salah satunya adalah motivasi siswa yang merasa tertarik dalam belajar dengan menggunakan model pembelajaran guided inquiry dengan mind map dan yakin akan apa yang telah dipelajarinya melalui proses pembelajaran.

Tingkat perhatian, keaktifan dan kepuasan siswa kelas eksperimen masih kurang dari pada kelas kontrol. Banyak hal yang dapat mempengaruhi hal tersebut, tetapi berdasarkan observasi peneliti memang masih ada beberapa siswa yang kurang perhatian, dan tidak begitu aktif dalam pembelajaran, sehingga tidak mendapatkan kepuasan dalam belajar. Peneliti beranggapan bahwa hal tersebut kemungkinan sesuai dengan kajian pustaka peneliti yang menuliskan tentang kelemahan dalam model pembelajaran guided inquiry, yaitu dipersyaratkan keharusan adanya persiapan mental untuk cara belajar dan harapan yang ditimpahkan pada strategi ini mungkin mengecewakan guru dan siswa yang sudah terbiasa dengan perencanaan dan pengajaran secara tradisional (Suryanti, 2010) 
karena model pembelajaran guided inquiry tidak pernah dilakukan di sekolah tersebut, siswa hanya melakukan penemuan atau praktikum melalui alat, bahan dan prosedur yang telah disiapkan. Sementara untuk model pembelajaran guided inquiry, siswa harus bisa berfikir dan bekerja keras atas inisiatifnya sendiri. Kemungkinan-kemungkinan lain juga boleh terjadi, akan tetapi peneliti memiliki kelemahan karena tidak dapat memperhatikan faktor-faktor penyebabnya dan tidak ada data awal yang menggambarkan bagaimana sebenarnya motivasi siswa sebelumnya.

Motivasi belajar dapat timbul karena faktor intrinsik, berupa hasrat dan keinginan berhasil dan dorongan kebutuhan belajar, harapan akan cita-cita. Sedangkan faktor ekstrinsiknya adalah adanya penghargaan, lingkungan belajar yang kondusif, dan kegiatan belajar yang menarik, tetapi harus diingat bahwa kedua faktor tersebut disebabkan oleh rangsangan tertentu sehingga seseorang berkeinginan untuk melakukan aktivitas belajar yang lebih giat dan semangat (Uno, 2008).

Motivasi belajar dapat dipandang sebagai $a$ general trait dan a situation-spesific state. A general trait, motivasi belajar diasumsikan sebagai suatu kecenderungan siswa yang relatif stabil dalam kegiatan pembelajaran, sedangkan situationspecific state, motivasi belajar diasumsikan sebagai suatu kecenderungan yang tidak stabil dalam kegiatan pembelajaran. Pandangan tersebut dapat diartikan bahwa motivasi belajar peserta didik bisa meningkat dan bisa menurun dalam situasi yang tertentu (Mustapa, 2009).

\section{Kesimpulan}

Ada pengaruh model pembelajaran guided inquiry dengan mind map terhadap hasil belajar siswa pada materi redoks di kelas X SMA Negeri 5 Palu dilihat dari skor rata-rata postest masing-masing kelas, yaitu kelas eksperimen $=$ 56,48 dan kelas kontrol $=46,25$. Hal tersebut diperkuat oleh analisis data statistik uji t-dua pihak diperoleh $\left.-\mathrm{t}_{\text {tabel }}\right\urcorner \leq \mathrm{t}_{\text {hitung }} \geq+$ ttabel $\left(\mathrm{t}_{\text {hitung }}\right.$ $=2,43$ dan $\left.t_{\text {tabel }}=1,67\right)$ dengan taraf signifikansi $\alpha=0,05$ dan derajat kebebasan 61. Sedangkan pada motivasi siswa, model pembelajaran guided inquiry dengan mind map tidak berpengaruh. Hal ini dapat dilihat dari hasil analisis angket motivasi siswa berdasarkan perhitungan statistik deskriptif yang menunjukkan bahwa kelas eksperimen berada pada sikap setuju dengan kategori positif yaitu $82,58 \%$ dan kelas kontrol berada pada sikap setuju dengan kategori positif yaitu $83,78 \%$.

\section{Ucapan Terima Kasih}

Penulis mengucapkan terima kasih kepada kepala SMA Negeri 5 Palu, guru kimia di SMA Negeri 5 Palu, siswa kelas X SMA Negeri 5 Palu dan semua pihak yang telah membantu penulis dalam menyelesaikan penelitian ini.

\section{Referensi}

Aini, F. N. (2011). Identifikasi pemahaman konseptual siswa kelas XII IPA-1 dan XII IPA-2 SMA Negeri 6 Malang tabun ajaran 201/2011 pada materi aplikasi reaksi redoks dan elektrokimia dalam kehidupan seharihari. Skripsi Sarjana pada Jurusan Kimia FMIPA Universitas Negeri Malang.

Aritonang, K. T. (2008). Minat dan motivasi dalam meningkatkan hasil belajar siswa. Jurnal Pendidikan Penabur, 10(7), 11-21.

Buzan, T. (2007). Buku pintar mind map untuk anak. Jakarta: PT Gramedia Pustaka Utama.

Dewi, N. D. L. (2012). Pengaruh pendekatan guided inquiry terhadap keterampilan proses IPA dan hasil belajar ranah kognitif peserta didik SMP. Skripsi Sarjana pada Program Studi Pendidikan IPA FMIPA Universitas Negeri Yogyakarta.

Hamdu, G. \& Agustina, L. (2011). Pengaruh motivasi belajar siswa terhadap prestasi belajar IPA di sekolah dasar. Jurnal Penelitian Pendidikan, 12(1), 81-86.

Kuhlthau, C. C. (2010). Guided inquiry: School libraries in 21st century school. School Libraries Worldwide, 16(1), 17-28.

Lukman, L. A., Martini, K. S. \& Utami, B. (2015). Efektifitas metode pembelajaran project based learning disertai media mind mapping terhadap prestasi belajar siswa pada materi pokok sistem koloid di kelas XI IPA SMA Al Islam 1 Surakarta tahun ajaran 2013/2014. Jurnal Pendidikan Kimia, 4(1), 113-119.

Maliha, M. (2011). Pengaruh model guided inquiry terhadap hasil belajar kimia siswa pada konsep laju reaksi (quasi eksperiment di kelas XI IPA SMAN 1 Leuwiliang). Skripsi Sarjana pada Program Studi Pendidikan Kimia FTK UIN Syarif Hidayatullah.

Mappeasse, M. Y. (2009). Pengaruh cara dan motivasi belajar terhadap hasil belajar 
programmable logic controller (PLC) siswa kelas III jurusan listrik SMK Negeri 5 Makassar. Jurnal MEDTEK, 1(2), 1-6.

Mulyasa. (2014). Pengembangan dan implementasi kurikulum 2013. Bandung: PT Remaja Rosdakarya.

Mustapa, K. (2009). Efektivitas pembelajaran problem posing dalam meningkatkan hasil belajar dan motivasi mahasiswa kimia universitas Tadulako. Tesis Program Pascasarjana Universitas Negeri Malang.

Mutrovina, N. \& Syarief, S. H. (2015). Meningkatkan keterampilan proses sains siswa melalui penerapan model pembelajaran inkuiri terbimbing pada materi reaksi reduksi-oksidasi di kelas X SMA Negeri 12 Surabaya. UNESA Journal of Chemical Education, 4(3), 466-471.

Purwanto. (2013). Evaluasi hasil belajar. Yogyakarta: Pustaka Pelajar.

Putri, C. A. I., Putra, K. N. D. \& Zulaikha, S. (2014). Pengaruh metode pembelajaran SQ3R terhadap hasil belajar bahasa Indonesia kelas V. Jurnal Mimbar PGSD Universitas Pendidikan Ganesha Jurusan PGSD, 2(1), 1-11.

Roestiyah, N. K. (2008). Strategi belajar mengajar. Jakarta: Rineka Cipta.

Sugiyono. (2010). Metodepenelitian pendidikan. Bandung: Alfabeta.

Suryanti, R. D. (2010). Strategi pembelajaran kimia. Yogyakarta: Graha Ilmu.

Uno, H. B. (2008). Teori motivasi dan pengukurannya. Jakarta: Bumi Aksara.

Wahyudin, Sutikno \& Isa, A. (2010). Keefektifan pembelajaran berbantuan multimedia menggunakan metode inkuiri terbimbing untuk meningkatkan minat dan pemahaman siswa. Jurnal Pendidikan Fisika Indonesia, 6, 58-62.

Wigiani, A., Ashadi \& Hastuti, B. (2012). Studi komparasi metode pembelajarn problem posing dan mind mapping terhadap prestasi belajar dengan memperhatikan kreativitas siswa pada materi pokok reaksi redoks kelas X semester 2 SMA Negeri 1 Sukoharjo tahun pelajaran 2013/2014. Jurnal Pendidikan Kimia, 1(1), 1-7.

Wiyatsih, K. (2011). Pengaruh penerapan model pembelajaran inkuiri terbimbing terhadap prestasi dan motivasi belajar siswa kelas $X$ SMA Negeri 1 Purwosari pada materi reaksi redoks. Skripsi Sarjana pada Jurusan Kimia FMIPA Universitas Negeri Malang.

Wulandari, A. D., Kurnia \& Sunarya, Y. (2013). Pembelajaran praktikum berbasis inkuiri terbimbing untuk meningkatkan keterampilan berpikir kritis siswa SMA pada Laju Reaksi. Jurnal Riset dan Praktik Pendidikan Kimia, 1(1), 18-26.

Zawadzki, R. (2010). Is process-oriented guided-inquiry learning (POGIL) suitable as a teaching method in Thailand's higher education. Asian Journal on Education and Learning, 1(2), 66-74. 